\title{
Students' Competency Focuses in Literacy at Language and Letters Faculty, State University of Medan (Unimed), Indonesia
}

\author{
Mara Untung Ritonga \\ State University of Medan (Unimed), Indonesia \\ achmadyuhdi@gmail.com
}

\begin{abstract}
The research aimed at describing Enlgish literacy competency of students, including information literacy. The rational of this research is taken from the vision of Universitas Negeri Medan which is planning to be a world class university. This educational institution which mostly supplies teachers should prepare students the better literacy competency. The first step to develop the competency is to do mapping about English literacy competency of students, including information literacy based on five information literacy standard of Association of College \& Research Libraries (ACRL) and The Australian and New Zealeand Institute for Information Literacy (ANZIL). The method used in the mapping is mixed methodology, qualitative and quantitative. The data of the research is 157 students from first and second semester of Indonesian letters Department. The tests done are reading, speaking, listening, speaking and writing, including students competency in accessing and understanding infromation in the internet. The result shows that English/information literacy competency of students vary (60\% low, 30\% medium, and $10 \%$ high). There fore, it is necessary to do some efforts to improve English literacy competency of students at the Department of Indonesian Letters Faculty of Language and Arts Universitas Negeri Medan.
\end{abstract}

Keywords: English literacy; information literacy; competency; mapping; literacy standard

\section{Introduction}

Literacy has become a popular isue that the government encourages this thing through National Literacy programme. This programme is one of the efforts to invigorate a synergy among official units; government and non-government organisation in ways of collecting all potencies and to broaden public involvement. By doing so, literacy activities become a culture in Indonesia (e.g. see, Smith and John A, 2009) as to improve national literacy is necessary to pack it in an integrated national movement which is not partial, individual and or is controlled by particular group (see also. Eithen Kennedy at.al. 2012) which did the development and improvement children literacy age 3-8 years.

It is of course universities are leaving no action, they should stand on the frontiest line to drive the literacy programme. In this respect, Universitas Negeri Medan as teachers supplier institution needs to prepare all its resources to support it and to improve its competency in ways of accessing information/knowledge in English, understanding it, and delivering it. English digital information; e-book and e-journal is important learning resources that students should be familar with. However, undergradute students, mainly the Department of Indonesian Letters, Faculty of Language and Arts, Universitas Negeri Medan have a low interest to such English materials. They said it is hard to understand, take time and money to 
translate it. More over, to express their opinion in speaking or writing, it is the hardest thing for them.

Moving from this daily experience, the mapping students English competency and programme to improve students English competency, including ablitiy to access English digital information are primary tasks to do. The mapping is done through activities : listening, reading, writing, and speaking. The results of the mapping and the ability test to access English digital information are used as the base step to revise the curriculum of KKNI. There fore, the Department of Indonesian Letters is expected to take some efforts to improve English students competency. One of the efforts is to revise KKNI curriculum, that is, plan to add four English subjects: 1) English, 2) English Literacy, English Translation, and 4) English for Academic Purpose.

Revising the curriculum of KKNI is very essential to produce the student's assignments quality, especially Mini Research, Critical Book Review, and Article Review. Those assignments require good English literacy competency and there fore, the student English competency should be improved. In the other hand, it is expected that the revision and the development and improvement programme to English student competency have significants effects on the better student academic quality and on their competitiveness for job opportunities.

\section{Literature Review}

CCSS determined the general base line and learning indicators encompassing four language skills; listening, reading, speaking and writing from children to adult learners. The base line and leaning indicators for literacy learning integrate linguistic knowledge and metacognitive to understand texts from varieties of fields (see. Murphy. S., 2003). This means that the knowledge and language competency are essential to measure the level of individual literacy in terms of listening, reading, speaking and writing. Language (bahasa) provides a significant contribution to other fields.

John S.Hedgcock \& Dana Ferris (2009) explored teaching materials and English teaching for ESL and EFL which focused on texts and contexts understanding in English teaching for ESL and EFL. This research is in line with Murphy S (2003) which is instead of understanding texts and contexts of its literacy, he showed the implicit and explicit literacy competency through language, symbol, gesture, and the like.

Another thing which is mainly important to improve students competency in the age of digital is literacy of information as Hasugian (2009: 200), explained that information literacy is a set of skills needed to search for, analyse, and use information. This idea is not much different from the research report by American Library's Association's Presidental Commite on Information Literacy (1989). It is said that "information literacy is a set of abilities requiring individuals to recognise when information is needed and have the ability to locate, evaluate, and use effectivelly the needed information.

Literacy is closely relation to the terminology of literated discourse. Literacy can widely be meant as the language competency covering the skills of listening, reading, speaking and writing and including thinking skill. Tompkins (1991: 18) argued that literacy is the competency to understand and use writing and reading materials in ways of doing jobs field and life out of schools. Different from this idea, Wells (2005) expressed literacy is competency to get along with discourse correctly as representation of experiences, thought, emotion, and opinion based on the purpose. But, how to understand the discourse if it is not 
read, and how to represent the feeling, thought, and emotion, if it is not written? That is why, Sulzby (1986) defined literacy as competency of reading and writing.

In conclusion, literacy is a language competency in listening, reading, speaking, and writing. Thought is becoming element within the competency. To be a literated person, he or she should have better knowledge in every activity needing literacy function effectivelly in a society, including in ways of understanding and producing texts and discourse. In the respect of information literacy, to ease and exelerate in ways of searching information, understanding, evaluating, and using the information, competency of information technology is abosuletly needed for someone to have information literacy. In that case, English literacy and information literacy are long life learning process which is becoming individuals capital in the terms of searching and understanding infromation, and literary resources.

\section{Research Methodology}

This research applies mixed methods; quantitative and qualitative to map the students English competency and information literacy competency. The subjects of this research are 157 studends of four classes (the 2016 and the 2017 student admission). Observation, interviews and tests are applied to get students competencty in listening, reading, speaking, and writing including ability to acess information. The research is done in the Department of Indonesian Letters, Faculty of Language and Arts Universitas Negeri Medan.

\section{Discussion}

The table 1 below describes the student English competency in listening, reading, speaking and writing. The test materials are four pages of texts ; Introduction to Linguitics and two foreign university brochures.

Table 1 Student English Competency: Introduction to Lingusitics

\begin{tabular}{|c|c|c|c|c|c|c|c|}
\hline Cat- & \multicolumn{3}{|c|}{ Reading } & Listening & Speaking & Writing & \multirow{1}{157}{} \\
\cline { 1 - 6 } & Pro & Speed & Comp & $\begin{array}{c}\text { Ask- } \\
\text { Answer }\end{array}$ & $\begin{array}{c}\text { Ask- } \\
\text { Answer }\end{array}$ & Summary & subjects \\
\hline Low & 101 & 115 & 85 & 91 & 96 & 98 & \\
\hline Med & 35 & 22 & 38 & 46 & 48 & 39 & \\
\hline High & 21 & 20 & 24 & 20 & 13 & 20 & 157 \\
\hline Sum & 157 & 157 & 157 & 157 & 157 & 157 & \\
\hline
\end{tabular}

Note:

Cat-: Category

Comp: Comprehension

Pro-: Pronunciation Speed: Reading Speed

The subjects competency in understanding the texts of two foreign university brochures is better than their competency in understanding texts of Introduction to Linguistics either in entirely language skill activities as it is showed in table 2 below.

Table 2 Student English Competency: two foreign university brochures

\begin{tabular}{|c|c|c|c|c|c|c|c|}
\hline Cat- & \multicolumn{3}{|c|}{ Reading } & Listening & Speaking & Writing & \multirow{1}{157}{} \\
& Pro & Speed & Comp & $\begin{array}{c}\text { Ask- } \\
\text { Answer }\end{array}$ & $\begin{array}{c}\text { Ask- } \\
\text { Answer }\end{array}$ & Summary & subjects \\
\hline Low & 98 & 96 & 65 & 73 & 57 & 95 & \\
\hline
\end{tabular}


birci.journal.org@gmail.com

\begin{tabular}{|c|c|c|c|c|c|c|c|}
\hline Med & 40 & 31 & 52 & 55 & 59 & 42 & \\
\cline { 1 - 6 } High & 19 & 30 & 40 & 29 & 41 & 20 & \\
\hline Sum & 157 & 157 & 157 & 157 & 157 & 157 & 157 \\
\hline
\end{tabular}

Whereas the student competency in accessing literacy information is done in the Digital Library Universitas Negeri Medan. The subjects are devided in to four groups in the different time to use the computer. The history of searching is erased every test season ends. The speed of accessing, understanding and evaluating information needed is scored using ask and answer activities. The table 3 displays the students competency.

Table 3 Student Competency in Accessing Literacy Information

\begin{tabular}{|c|c|c|c|c|}
\hline Category & Speed & Understanding & Evaluating & 157 Subjects \\
\hline Low & 67 & 80 & 95 & \\
\hline Medium & 52 & 57 & 61 & \\
\hline High & 38 & 20 & 11 & \\
\hline Sum & 157 & 157 & 157 & 157 \\
\hline
\end{tabular}

The table 1 and table 2 have shown us students English competency in the different type of texts: knowledge of language and knowledge of information. In every four language skills is seen different competency : low category $(101,115,85,91$, and 98) respectly compare to student competency for texts of brochures/ information $(98,96,65,73,57$ and 95). While the medium category also shows fewer students have better competency for texts of linguitics compare to texts of information; e.g. 48, and 39 (speaking and writing) to 59 and 43. The same situation is also found in the high category; e.g. 13 and 20 (text of linguistic) for speaking and writing test compare to 42 and 20 for the texts of information. Based on the table 1 and 2, it may be highlighted that the lowest student English competency is firstly writing, and secondly, speaking. The percentage of overall competency taken from two tests (table $1 \& 2)$ are low $(60 \%)$, medium (30\%) and high (10\%).

Reading tests show that student also find some problems in the pronunciation and reading speed (see table $1 \& 2$ ). The result etremely effects on their competency in listening and speaking (ask and answer) activities for they are not familiar with English sound, vocabulary, and the meaning. In addition, the knowledge of context is also so low that they do not understand the meaning of the words except looking at the dictionary. Fewer students took part in the speaking activity when discussing the two texts given, mostly become good audiences.

Finally, the student literacy information competency shows better results compare to English literacy. Even though they are accessing information in English, they are easier to understand and evaluate the texts for the visual and media help (see. Table 3 above) which mostly shows average score along side the category of low-medium-high.

\section{Conclusion}

Based on the result and explanation of the research it may take some conclusions that the students English competency of the Department of Indonesian Letters are low $(60 \%$ low category, $30 \%$ medium, and $10 \%$ high). The students's problems are not just reading, listening, speaking and wirting, but also, pronunciation, grammar, vocabulary, meaning, discourse and contexts. There fore, it is necessary to improve students English competency through the programme of develoving and improving students English competency. The programme may in the terms of learning projects and additional English subjects: English, 
English Literacy, English translation and English for Academic Purpose. The revison of KKNI curriculum is also needed to produce better qualified students and their assigsments.

\section{References}

John A.Smith.(2009) Literacy Issues During Changing Times : A Call to Action. Arlington: Texas A\&M University Commerce.

Kennedy Eithene at.al (2012). Literacy in Early Childhood and Primary Education (38years). National Council for Curriculum and Assessment24: Merion Square Dublin

Kansas College and Career Ready Standards. (2010) English Language Arts and Literacy in History / Social Studies ,Science, and Technical Subject. Common Core State Standards ( CCSS).

John S. Hedgock \& Dana Ferris (2009). Teaching Readers of English : Student, Textts, and Contexts. New York and London : Routledge Taylor \& Francis Group.

Moleong,Lexy . ( 2002 ). Metodologi Penelitian Kualitatif . Bandung : PT .Remaja Rosdakarya.

Murphy. Sharon . (2003) . Teaching and Learning in Context. Boston : National Council of Teachers of English. 